\title{
Regional Police Role Of Central Java In Prevention Of Domestic Violence Act In The Family
}

\author{
Wina Angrayini ${ }^{1}$ and Sri Endah Wahyuningsih ${ }^{2}$
}

Abstract. Domestic violence is still a lot going on regardless of social strata, economic, age, education level even. Polri plays an important role in the prevention of the domestic violence act. The problem is analyzed using the theory and the theory of crime prevention role. The results showed that the Central Java Police's role in the response to domestic violence is at the preventive and repressive efforts. Preventive efforts to optimize the function Binmas in executing is Bhabinkamtibmas by conducting outreach and dissemination to the public. While the repressive efforts carried out through investigation procedure as the provisions of the legislation applicable to the mediation efforts remain to be done. The obstacles that appear in the response to domestic violence in the Central Java Police is the public perception of the cases of domestic violence is considered a regular problem and not a criminal case, the lack of a witness in the trial of domestic violence, limited human resources and infrastructure to protect the victim. As an attempt to overcome these obstacles is to change the public perception that by doing counseling and socialization of domestic violence is routine and ongoing, came to address the witness for questioning as a witness, working with agencies / NGOs and by following the development education specialist of Polwan PPA. Associated with limited facilities and infrastructure in the protection of victims is cooperation with NGOs that provide shelter.

Keywords: Prevention; Domestic Violence Act

\section{Introduction}

Domestic violence has long lasting in the community, it is only unknown quantity in number, such as violent husband to wife or husband against female domestic helpers. Violence shape ranging from abuse, rape and so on. ${ }^{3}$ Legal reforms in favor of vulnerable groups or subordinate, particularly women, become indispensable due to the many cases of domestic violence. Therefore, the need for regulation of the crime of domestic violence in isolation because it has a specific, although generally in the Code of Penal (Penal Code) has been arranged on torture and decency as well as neglect of people who need to be given sustenance and life.

Cases of violence against women in Central Java province is quite high. In 2017 there were at least 352 cases of violence against women. Of the 35 districts / cities in Central Java, Semarang became the highest city cases of violence against women with 118 cases. Of the hundreds of cases of violence against women, cases of domestic violence (domestic violence) became the most cases in 2017, which reached 117 cases or 33.3

\footnotetext{
1 Student of Master of Law, Universitas Islam Sultan Agung Semarang and Polri, email: winaangrayini@gmail.com

${ }^{2}$ Lecture of Faculty of Law UNISSULA Semarang

${ }^{3}$ Guse Prayudi, 2009, Berbagai Aspek Tindak Pidana Kekerasan Dalam Rumah Tangga, Yogyakarta : Merkid Press, 2009, p. 16.
} 
percent of the total. ${ }^{4}$

To overcome the problem of domestic violence is required various actions at once. Parties are considered authorities and competent in handling cases of violence are public figures, government officials came to the village level, police, social workers, educators and health professions.

The Police have a very important role in dealing with cases of domestic violence, given the result of a criminal act, the victim may experience physical and psychological suffering that is very deep and prolonged. It is as set out in Article 5 of Act No. 2 of 2002 on the Indonesian National Police stated that the police are the tools the state that play a role in maintaining security and public order, enforcing the law, and to provide protection, shelter and services to the community in order the maintenance of internal security. Police service provided to the public by way of receiving any reports and complaints from the public within $1 \times 24$ hours.

Based on the above background, the authors are interested in doing research on "Regional Police Role Of Central Java In Prevention Of Domestic Violence Act In The Family". Based on the description of the background described above, then the problem is formulated as follows: 1) What is the role of the Central Java Police in the prevention of domestic violence act? 2) Which barriers appear in the response to domestic violence in the Central Java Police and how attempts to solve it?

\section{Research methods}

The approach used in this study is a sociological juridical approach. ${ }^{5}$ The specifications of the research is descriptive. The data used are primary data and secondary data collection methods of field studies and literature. The method of data analysis using qualitative analysis.

\section{The Results And Discussion}

\subsection{Central Java Police Role in Combating Domestic Violence Act}

Police role in the prevention of domestic violence is very important. This is because the Police is spearheading the criminal justice system in Indonesia. The Role of the Central Java Police in tackling domestic violence acts is to undertake preventive and repressive efforts. ${ }^{6}$

- Preventive Measures

Preventive measures is any act or activity undertaken to prevent domestic violence. Domestic violence prevention preventive measures carried out in the form of education and socialization activities as set forth in Article 11 of PKDRT Law which states that the government is responsible for the prevention of domestic violence. To carry out the role of the Central Java Police carry out the following activities: ${ }^{7}$

- Extension Activities to The Public ; Counseling is one form of preventive activities carried out by the Central Java Police to prevent domestic violence by providing an

\footnotetext{
4 Jateng Tidak Ramah Terhadap Perempuan, (https://www.jawapos.com, Accessed 20 April 2018).

${ }^{5}$ Ronny Hanitijo Soemitro, 1989, Metodologi Penelitian Hukum dan Jurimetri, Ghalia, Jakarta, p.9.

${ }^{6}$ Interview with AKBP Wahyu Purwidiarso as visible in the Central Java Police, dated August 20, 2018 in Semarang.

${ }^{7}$ lbid.
} 
understanding of domestic violence as well as the legal consequences to the public, especially residents of Semarang. This extension activities aimed at providing information and understanding to the community that domestic violence includes criminal acts that should be avoided, for the community to be able to protect themselves, inviting the public to prevent acts of domestic violence and protect victims of domestic violence and provide information to the public legal procedures handling domestic violence cases.

- Socialization of the Law on the Elimination of Domestic Violence[ The socialization activities that are informative and educative implemented by PPA Unit in collaboration with Bhabinkamtibmas and some NGOs in Semarang with the involvement of religious leaders, community leaders and youth leaders. In this case the Central Java Police coordinate with the community through the dissemination of Act No. 23 of 2004 on the Elimination of Domestic Violence explicitly governing penalties for perpetrators of domestic violence which is expected to reduce the occurrence of crime in the household.

- Repressive Measure

Efforts repressive countermeasures include enforcement of domestic violence by means of direct action based on the reports of victims of domestic violence which include, arrest, examination, investigation until firm steps in accordance with the criminal offense he had done. Repressive domestic violence prevention efforts carried out by the PPA Unit Central Java Police who acted as the investigator. Based on the interview with Mr. Joko obtained information that in dealing with domestic violence cases to prior negotiations with the victim in order to be resolved amicably. Efforts to resolve the matter amicably in accordance with the dispute resolution theory is done through non-litigation. In this case the PPA unit acts as a mediator / facilitator. $^{8}$

Broadly speaking police duties in addition to a law enforcement agency as well as the keeper of security and public order. National police task can be divided into the preventive and repressive. Preventive measures carried out with a view to preventing crime plaguing the society, while the repressive efforts through a series of investigative actions. The aim is that the offender can be brought to court to be held accountable / sanctions. ${ }^{9}$

As part of the criminal justice system, the police is the leading organ for the enforcement of the law. Unsticking the Police on duty parse crime by the investigation. In the implementation of this task required the professionalism of the Police to be able to catch the perpetrators. Because if not, then the public will still be threatened by aberrant behavior of criminals. ${ }^{10}$

Both the above police duties are two sides of the functions of the Police. In reviewing prevention of violent crime through the criminal justice mechanisms, police portray law enforcement functions. Police function as law enforcement is to prevent people becoming victims of crime and resolving crimes that occurred with the capture and

\footnotetext{
8 Interview with AIPTU Agus Suliyadi as PPA of Central Java Police Investigators Unit, dated August 23, 2018 in Semarang.

${ }^{9}$ M. Khoidin dan Sadjijono, 2007, Mengenal Figur Polisi Kita, Yogyakarta, LaksBang, p.58

${ }^{10}$ Ibid.
} 
expose perpetrators to justice. ${ }^{11}$

Judging from the theory of crime prevention, efforts to combat domestic violence acts in accordance with the theory of crime prevention which states that efforts to tackle crime have two ways of preventive (prevent prior crimes) and repressive measures (venture after the crime). Preventive measures carried out by means of education and socialization to the community to prevent the occurrence of acts of domestic violence, while the repressive efforts undertaken by law enforcement through investigative action.

Efforts to combat domestic violence acts by the Central Java Police have appropriate role theory. This is as stated by Soerjono Soekanto which states that the role or the role of behavior patterns associated with status or status as a pattern of behavior. If a person is exercising its rights and obligations in accordance with the position then he runs a role. ${ }^{12}$ Efforts to combat domestic violence acts by the Central Java Police has fulfilled the role of the elements of the role and the role of normative ideal. Normative role Central Java Police in tackling domestic violence acts both preventive and repressive based on the legislation in force, namely the Criminal Code, Act No. 2 of 2002 on the Indonesian National Police, the Law of the Republic of Indonesia Number 23 of 2004 on the Elimination of Violence Domestic and Police Regulation No. 3 of 2015 on Community policing. In carrying out the duties and authority as the Central Java Police law enforcement officers in accordance with regulations by acting as a protector for the community in order to realize order, security, which has the ultimate goal of public welfare.

\subsection{Obstacles that Comes in Combating Domestic Violence in the Central Java Police and Efforts to Overcome}

Reduction efforts of domestic violence do not always go smoothly, because there are barriers that sometimes arise. These barriers are: ${ }^{13}$

- The Public Perception Of Domestic Violence Cases

People are still embedded in the culture of shame to report domestic violence to the police. As a result, many cases of domestic violence experienced by the wife of unreported cases of violence against wives always repeated. There was also still a perception that the husband has the right to do anything against her (the wife must obey the husband). This is because the majority of people in Central Java are Muslims, whereas in Islam the wife shall obey the husband. The teachings are sometimes not well understood by the general public, for the general public so that the husband has the right to do anything against his wife. As a result, despite receiving threats of violence from the husband, the wife did not take the fight and also reported to the authorities.

To overcome these obstacles is to change the public perception that by doing counseling and socialization of domestic violence is routine and ongoing. This is

\footnotetext{
${ }^{11}$ Mardjono Reskodiputro, Hak Asasi Manusia Dalam Sistem Peradilan Pidana, Pusat Pelayanan Keadilan dan Pengabdian Hukum, Lembaga Kriminologi U.I, Jakarta, 1994, p. 161.

${ }^{12}$ Soerjono Soekanto, 1983, Pengantar Penelitian Hukum, Rineka Cipta, p.72

13 Interview Agus Suliyadi, op.cit
} 
because changing the dominant perception of society does take a long time. Implementation of counseling and cooperate sosiliasi with NGOs and community empowerment through encouraging community leaders, religious leaders and youth leaders.

- The Lack Of A Witness In The Investigation Of Domestic Violence Cases In the process of examination of the crime of domestic violence, takes the witness for questioning related to the crime that happened. However there are some witnesses who are not willing to come to the police station for questioning as a witness. Attempts by investigators to handle it is to come to address the witness for questioning as a witness.

- Limited Human Resources

Limited human resources in question was the absence of psychologists, maximal care in the handling of domestic violence related khsusunya the protection of victims such as counseling by the police to the victim, the police lack of understanding of the importance of protection orders for victims. Unit PPA Board of the Central Java Police still minimal personnel specifically to handle victims of psychological pressure or officer who understands the psychological condition of the victim. There are even some police who are less experienced in handling and treating victims of domestic violence. In addition the police do not understand the procedures for requesting and criteria as to what an act of domestic violence that afflicts the victim may be requested protection orders so that there are still victims who are repeatedly exposed to violence.

Central Java Police efforts made to overcome the lack of psychologists who can provide psychological assistance / counseling to victims of domestic violence are working with agencies / NGOs. Related to the lack of knowledge of members of the Police, resolved by following the development of education specialists Polwan PPA. This is to improve the understanding of PPA members on issues related to gender and improve the skills of how to handle or treat victims of the members of Unit PPA given the opportunity to participate in education and training organized by the Institute of Education of Police (Lemdikpol). The study aims to improve the knowledge and skills PPA police in handling women and children who are victims of crime.

- Limited Facilities And Infrastructure In The Protection Of Victims

Unit PPA there should be a break room whose function is similar to the safe house that serves as the resting place of the victim as complainant and witnesses. Central Java Police Unit PPA does not have a break room that can be used as a resting place for victims who need a break to calm down and avoid the threat of the perpetrator. It is certainly difficult when there are victims who need temporary shelter to keep him. To overcome this done in cooperation with NGOs that provide shelter.

\section{Closing}

\subsection{Conclution}

- Central Java Police role in the prevention of domestic violence acts are the preventive measures and repressive efforts. Preventive efforts to optimize the function Binmas in executing is Bhabinkamtibmas by conducting outreach and dissemination to the 
public. While the repressive efforts carried out through investigation procedure as the provisions of the legislation in force. However, during the investigation process is still being done mediation efforts. If the two sides reached the peace efforts, the case is discontinued, but if mediation fails to proceed with the filing of cases and delegation to the prosecutor.

- The obstacles that appear in the response to domestic violence in the Central Java Police is the public perception of the cases of domestic violence is considered a regular problem and not a criminal case, the lack of a witness in the trial of domestic violence, limited human resources and infrastructure to protect the victim. As an attempt to overcome these obstacles is to change the public perception that by doing counseling and socialization of domestic violence is routine and ongoing, came to address the witness for questioning as a witness, working with agencies / NGOs and by following the development education specialist Polwan PPA. Associated with limited facilities and infrastructure in the protection of victims is cooperation with NGOs that provide shelter.

\subsection{Suggestion}

- It needs a regular and ongoing socialization to the public related to the domestic violence act.

- Need for community participation in prevention of domestic violence acts.

- Need the participation of government and related agencies in the prevention of domestic violence acts.

\section{Bibliography}

[1] Guse Prayudi, 2009, Berbagai Aspek Tindak Pidana Kekerasan Dalam Rumah Tangga, Merkid Press, Yogyakarta.

[2] Soerjono Soekanto, 1983, Pengantar Penelitian Hukum, Rineka Cipta, Jakarta.

[3] Ronny Hanitijo Soemitro, 1989, Metodologi Penelitian Hukum dan Jurimetri, Ghalia, Jakarta.

[4] M. Khoidin dan Sadjijono, 2007, Mengenal Figur Polisi Kita, Yogyakarta, LaksBang.

[5] Ronny Hanitijo Soemitro, 1989, Metodologi Penelitian Hukum dan Jurimetri, Ghalia, Jakarta.

[6] Constitution of the Republic of Indonesia of 1945

[7] Book of the Criminal Justice Act

[8] The Code of Criminal Procedure

[9] Act No. 2 of 2002 on the Indonesian National Police.

[10] Law of the Republic of Indonesia Number 23 of 2004 on the Elimination of Domestic Violence.

[11] Indonesian National Police Chief Regulation No. 14 of 2012 concerning the Crime Investigation Management.

[12] Arum Yuana, Peranan Unit Pelayanan Perempuan Dan Anak Kepolisian Resort Kota Yogyakarta (Unit Ppa Polresta Yogyakarta) Dalam Perlindungan Perempuan Korban Kekerasan Dalam Rumah Tangga, 2 Jurnal Civics, September 2017

[13] Jateng Tidak Ramah Terhadap Perempuan, (https://www.jawapos.com, Accessed 20 April 2018). 